\title{
Disease, Dislocation and Deprivation in Louise Erdrich's The Birchbark House: Exposing the White lies of the Civilizing Discourse
}

\author{
Virender Pal \\ Department of English, Institute of Integrated and Honors Studies, Kurukshetra University \\ Kurukshetra. ORCID: oooo-ooo3-3569-1289. Email:p2vicky@gmail.com \\ First published July 19, 2019
}

\begin{abstract}
When the colonizers reached America, they came across people who held a totally different view of the world and their surroundings. In their world they were not the masters of the animate and inanimate world, rather they were a part of it. This world view did not conform with the culture of Europe, so they started denigrating them; but the reasons behind denigration of the Natives were deeper as exposed by the narratives of the Native Americans. The whites were not interested in de-culturing or a-culturing the Natives, they were interested in the land occupied by the natives. For usurping the land; they started denigrating the Natives and referred to them as uncivilized barbarians. Some of the narratives even featured them as cannibals. The natives did not have any idea about what was written about them, but now the tide has turned and the Natives have started writing narratives that project their world view. These narratives written by the Natives not only demolish stereotypes, but also try to revive their culture. The Native writers try to reorient the consciousness of the readers and instigate them to uncover the true history of the oppressed people. These kind of texts have been termed as 'autoethnographic' narratives. Louise Erdrich is one of the most prominent Native writers who is trying to construct a new identity of her people by scattering the mist created by the colonial narratives. The current paper is a study of Louise Erdrich's novel The Birchbark House.
\end{abstract}

Keywords: Colonial, Natives, culture, Ojibwe

Colonialism was an enterprise that made "racial and ethnic inequality appear as natural, justified and desirable" (Pols, 2011, p. 111). The people who were invaded and colonized were branded as "Savage" (Lewis, 1993, p. 221). However, the use of adjectives or nouns for the invaded people depended on the convenience of the invader. 'Savage' was comparatively mild word used for the invaded as it referred to a person who was "naked without shame, unconcerned about private ownership and accumulation of material wealth" ( Prucha, 1984, p.7). The more atrocious words used for the colonized were "cannibals" and practitioners of "human sacrifice" (Washburn 1957, 49). The colonial commentators of Native life noted "the squalor, the filth, the indolence, the lack of discipline, the thievery and hard lot accorded to Indian women" (Prucha, 1984, p. 7). In the later stages of colonialism, the boundaries between "Savage" and "cannibal" blurred and the

(C) AesthetixMS 2019. This Open Access article is published under a Creative Commons Attribution Non-Commercial 4.0 International License (http://creativecommons.org/licenses/by-nc/4.o/), which permits non-commercial re-use, distribution, and reproduction in any medium, provided the original work is properly cited. For citation use the DOI. For commercial re-use, please contact editor@rupkatha.com. 
people of the colonizer's country started equating "savage" with the "cannibal." With this blurring of boundaries, the task of colonizer was complete. Now because colonized were "cannibals," any violence against such barbarians was justified. With this colonialism which was intended to loot the natural resources of the colonies became a philanthropic exercise of spreading "civilization" among the uncivilized and "culture to the non-literate" (Ryan 1981, p. 4). The murderer and usurper colonizer posed like "a noble adventurer, a righteous pioneer" (Memmi, 1991, p. 3).

The "collective hypocrisy" (Cesaire, 2010, p. 32) of the colonizers has been revealed by the theorists like Frantz Fanon, Albert Memmi, Aime Cesaire and Homi J. Bhaba etc. These theorists 'pierced through the veil of the colonialism' and showed how it worked. They showed how the colonial power relied "on barbaric, brutal violence and intimidation" (Kelley, 2010, p. 9). The distortions about the colonized were laid bare in front of the whole world. The work of these theorists was followed by the writers of the occupied territories. While the theorists of colonialism worked to destruct colonialism, to reveal the hidden face and mechanism of the colonial machinery; the creative writers started the work of construction; construction of their history, culture and civilization. In the process of constructing their identity, they exposed the lopsided history of the books written by the colonizers which focused only on the "blessed intervention" of the whites. Chinua Achebe exposes the typical attitude of the white travelers by citing the example of Marco Polo who travelled from the Mediterranean to China. After coming back, he wrote a book entitled Description of World. In his book, he failed to mention the "art of printing" and "the great wall of China" (Achebe, 1977, p. 8). The colonial writers followed suit and edited out all the achievements of the Natives from their narratives. The Native writers have started filling the gaps left by the colonial narratives.

Louise Erdrich is one of the most prominent Native American writers. She has written books about her own community. Her books not only reconstruct history of the Natives, but also concentrate on the problem faced by Natives in the present day Unites States of America. Her novel The Birchbark House (1999) is the first novel of her tetralogy that concentrates on the history of her people. The paper is the study of the novel The Birchbark House.

The novel, The Birchbark House is representative of those texts which are placed in the genre "autoethonographic" texts (Pratt, 1991, p. 37). According to Jaskoski (1996), there are many aims of texts like The Birchbark House:

Their aims are several: to preserve and explain their nations' pasts, to correct erroneous or biased ideas about Indians'; to argue for compliance with treaty obligations; to present themselves as models contradicting stereotypes of savagism; and to promote better treatment, especially better education, for Indians. (p. 137)

The novel not only tries to resuscitate the culture of the natives; but also shows how dislocation affected the culture of the Ojibwe. While telling the tale, the writer peels off the "philanthropic and benevolent" (Washburn, 1968, p. 49) gloss of the policy of dislocation of her people from their native lands. The novel makes it clear that the native culture was closely linked to the land; so dislocation also meant obliterating the culture. At the same time the novel also questions the civilization etiquettes of the whites who cheated Indians in the treaties and used disease as weapon of war.

The novel shows how Omakayas's family spends one year on their traditional land. In the course of telling what happens during this one year, Erdrich shatters many stereotypes of Indians and shows how the culture of her people is best suited for the place. In other words, she reconstructs the culture and history of her people and unravels the betrayals done by the whites. 
She herself tells about the motivation: "I want to be able to present Indians as sympathetic characters, non-stereotype characters that any non-Indian would identify with" (Coltelli, 1990, p. 26).

These kind of writing projects of "respectable, reliable, properly qualified wordsmiths" (Langton 1999, p.1) like Louise Erdrich are important because they are competent to tell the truth about their people. The majority of the people in society believe that Natives are "a race of degraded, brutal races of savages" (Whipple, p. 1880, V). The success of colonial narratives is evident from the fact that current generation has grown up thinking the colonialism of such lands was a "heroic achievement" (Stearns , 2003, p.493). Sidner Larson also points out the same thing:

Justification of the destruction of American Indians has been so successful, that contemporary majority culture has effectively suppressed acknowledgement of wrongs and ignores the continuing genocide. (2000, p.21)

The books like The Birchbark House presents the other side of story. It is a counterhistory told in fiction. The important point about the book is that it is not confrontationist. In the novel, the novelist focuses on the lives of the Natives; comments on the atrocities committed by the whites are lacking. The main aim of the novelist is to "celebrate survival, resist erasure, and transmit culture and history" (Wong, Hertha D. Sweet, 2008, p. IX). The novelist deliberates on the resuscitation of culture. The project is important because the human beings are distinguished by culture. The importance of culture is evident from the definition given by Corin:

Above all a system of meanings and symbols. This system shapes every area of life, defines a world view that gives meaning to personal and collective experience and frames the way people locate within the world and believe in it. Every aspect of reality is seen embedded within the webs of meanings that defines a certain world view and that cannot be studied apart from this collective frame. (Corin, 1995, p. 272)

The important words in the definition are "certain world view." These words indicate that the culture is not universal and it depends on the local factors like available raw materials, geography, climate etc.

Blinded by "ethnocentrism," the whites used their own culture as a yardstick for judging the ways (Henslin, 2005, p. 37) of the Natives which lead to a negative evaluation of their values, norms and behaviors, the Europeans subsequently branded the Native culture as inferior. The culture of Natives was declared outdated which needed to be obliterated.

Erdrich shows that Native culture was not inferior, rather it was best suited to survive in those particular conditions. For instance, in the opening pages of the novel, Erdrich tells that "all winter long Omakayas's family lived in a cabin of sweet scented cedar at the edge of the village of La-Pointe" (Erdrich, 1999, p. 6). During the course of the novel the readers come to know that the family lived in different houses during the different seasons. Now the choice of building material for the houses of different seasons is also important. The winter house is constructed with "Sweetscented Cedar." The choice of "Sweet-Scented" wood for winter house is extremely important because during the harsh winters, the family had to remain confined to the house only. During these long and biting winters the "sweet scent" of the cedar must have saved the people from the stench generated during the long confinement. On the other hand, the summer house was made of "birchbark" because it could be stitched and the tightly stitched birchbark could stand "the force of the gusts of winds (1999, p. 13). The housing material used by the Natives indicates the excellent use of locally available material. 
The whites watched all this, but they did not acknowledge the wisdom of the Natives because their culture was totally different. One of the differences was in the manner in which Natives and whites related to the land:

The settlers tended to think of the bounty offered by their new environment as inexhaustible. They were not nearly as aware of the rhythms of nature as Indians were; nor did they know how to live in the harmony with nature without destroying its resources. (Kornblum, 2000, p. 58)

The Natives believed that all the living things had "indwelling spirits" (Cushner, 2006, p. 14). In Native culture, man was not central point of creation rather he was a part. On the other hand, Western man thought "Man as a ruler of Natural world" (Cushner, 2006, 14):

The book of Genesis gave humans domination over the land, seas and animals of the universe. God did not dwell in nature, but ruled over it and he gave to man, his creation the power to do with it whatever man wished. (Cushner, 2006, p. 14)

Louise Erdrich shows how the respect for the natural world was an integral part of Native culture. Before taking birch bark from the tree, Nakomis offers "sweet and fragrant" (1999, p. 8) tobacco and asks for permission of the tree: "Old sister, we need your skin for our shelter" (1999, p. 7). In this world owl is considered as "Grandfather" (1999, p. 13) and a crow can be taken as a pet (1999, p. 70).

In this world animals and human beings live together and their lives are connected to one another. They hunt animals, but that is only for food, and forgiveness is sought every time before a hunt:

Omakayas was now felt badly about betraying them and as she drove the birds into the net she begged them to forgive her, saying the words she heard her grandmother use, "forgive us, forgive us, we have need." (1999, p. 58)

The life style followed by the Natives made sure that the species are preserved; on the other hand, white man's life style, culture and beliefs pushed away species to extinction and created "the scarcity of food" (1999, p. 167).

Animals are not the companions in this culture; but they also act as teachers. Erdrich shows how her people, the Ojibwe learnt to use different herbs/plants as by observing the bears. They are referred to as "people" (1999, 207):

Nokomis told Omakayas that bears dig for medicine. They are a different kind of people.... They eat the same things we do and treat themselves with medicine from certain plants. They are known as healers. (1999, p. 207)

The body of knowledge was formed after careful observation:

Nokomis had after shown Omakayas signs of where bears dug rocks or tore leaves, roots and fruits into their mouths... It was important to watch them very closely what plants they ate and which they avoided. (1999, p.107)

All this knowledge of medicine plants was imbibed into culture over the centuries. Now if these cultures allowed to go extinct then this precious knowledge will be lost and the surviving Natives will face serious health issues. A report "Progress can kill" reports such a case:

Low levels of iodine in Papua New Guinea soils could lead to nutritional problems, but local people developed traditions of evaporating water from iodine rich mineral springs. 
When the government and missionaries started paying local with shop bought low iodine salt, these traditions were abandoned, iodine levels in the diet decreased and there was an explosive epidemic of goiter and cretinism. (2007, p.16)

Erdrich is also critical of government and missionaries for pushing the Native culture to brink of extinction. This is important because most of the white commentators of the colonial era considered missionaries as an important tool for 'civilizing' the Natives. Native writers like Erdrich not only bring out the real nature of missionaries' work, but also expose the biased commentaries of their accounts. Consider, for example, the comments of the Bernard W. Sheehan on contribution of the missionaries to Native society:

The introduction of Native civilized medicine, the discouragement of dancing and ball play, the elimination of elaborate and prolonged mourning, and the attack of the polygamy, infanticide, whiskey drinking and obscene conversation all bore heavily on the alteration of native society. (p. 276)

Erdrich in her novel acknowledges the missionaries for introducing modern medicine to control small pox (p.143). While approving the missionary work in introducing vaccine for the control of "White Man's disease" (p. 58), the writer again stresses that their culture was rooted in their native land. They had medicine and cure for all the local diseases, but their medical knowledge is helpless before the "White Man's Disease."

Omakayas' little brother Neewo dies due to small pox. Erdrich probably included this episode to stress two points: the devastation caused by small pox and the death related beliefs of her people. Bernard W. Sheehan remarked that missionaries influence was important in doing away with "elaborate and prolonged mourning", but here Erdrich introduces a non-Christian Indian family that believes that "Ojibwa must walk a path that leads out of this life into the next" (p. 150).The episode shows that death is just a path to reach the spiritual world. Whatever Erdrich writes about Native attitude towards death is also confirmed by the other Indians writers, Vine Deloria Jr. for instance writes:

The singular aspect of Indian tribal religions was that almost universally they produced people unafraid of death. It was not simply not the status of a warrior in the tribal life that created a fearlessness of death. Rather the integrity of communal life did not create an artificial sense of personal identity that had to be protected and preserved at all cost. (1994, p.178)

The Natives were not afraid of death, but these epidemics of small pox did play their role in obliteration/ debilitation of Native cultures. Culture is "learned... through observation and imitation." (Anderson \&Taylor, 2004, p.59) and through "formal and informal transmission" (Anderson \& Taylor, 2004, p.59). Another definition of culture by Hofstede stresses on collective nature of culture:

The collective programming of the mind that distinguish one group or category from another. This stresses that culture is (a) collective not individual attribute; (b) not directly visible, but manifested in behavior and (c) common to some but not all people. (p. 52)

All the above definitions of culture stresses that culture can be "learned" or "transmitted" when a person is living in a group. The epidemics of small pox wiped out whole communities of the Natives which did not allow the culture to be transmitted. In The Birchbark House, the readers come to know that Omakayas originally belonged to "an island called Spirit Island" where everyone but Omakayas "died of itching sickness" (p. 233). Culture of that island vanished from 
the face of earth because nobody capable of transmitting culture to Omakayas survived. Omakayas learned the culture of the Island of Golden-Breasted Woodpecker, but her own culture was lost. With the loss of that culture, humanity lost an important body of knowledge.

Transmission of culture is not affected only by the death of everybody in community. It is also affected by reduced number of elders in the community. There are some specialized cultural capabilities which are restricted to only a few people. For instance, in the Native community of the island only "seven or eight people possessed the right to give names" (39). Gerald Vizenor points out that "Individuals were given special names, at birth... in the traditional past, a person in the tribe was selected to present a sacred name to a child" (1984, p. 13)

Similar is the case of healers or medicine men. In the traditional society all and sundry could not act as a healer. Omakayas is destined to become a healer because of her special affinity to "bear people" (p. 170). Moreover, she is not selected by Nokomis to be a healer, rather she "was chosen to be a healer" (p. 206) by the spirits. All these specific cultural practices were disrupted due to the outbreaks of small pox. These outbreaks could be compared with the Black death of 1348 in which London lost almost one third of its population (Sanders,1994,p.49) and the number of parish clergy were "severely depleted" that affected the religious services for years to come (Sanders, 1994, p. 49).

The novel is not meant for the Native readers only; it targets the white readers as well. The text involves:

A selective collaboration with and appropriation of idioms of the metropolis or the conqueror. These are merged or infiltrated to varying degree with the indigenous idioms to create self-representations intended to intervene in metropolitan modes of understanding. Auto ethnographic works are often addressed to both metropolitan and audience and the speaker's own community. There reception is thus highly in terminate. Such texts often constitute a marginalized group's point of entry into the dominant circuits of print culture. (Pratt, 1991, 35)

The Birchbark House also as a "point of entry" in dominant white society makes adjustments to suit to the needs. Louise Erdrich refrains from commenting directly on the outbreaks of the small pox. She does not hurt the sensibilities of whites by blaming them for the outbreaks, but the two references in the novel about the outbreak are powerful and moving enough to inspire readers to do a bit of research about the outbreaks. A bit of research in history of outbreaks introduces the readers to the works of historians like William Warren who thought that "small pox was deliberately introduced by the colonizer as a weapon of war or revenge" (Jaskoski, 1996, p.149-50). Another historian, Francis Parkman (1851) has unearthed an exchange of letters between Colonel Henry Bouquet and Sir Jeffrey Amherst. In a letter, Amherst made this sinister suggestion:

Could it not be contrived to send small pox among those disaffected tribes of Indians? We must on this occasion use every stratagem in our power to reduce them. (p. 305)

To this Bouquet replied:

I will try to inoculate the ---- with some blankets that may fall in their hands, and take care not to get the disease myself. As it is pity to expose good men against them, I wish we could make use of Spanish method, to hunt them with English dogs, supported by rangers and some light horse, who would, I think, effectually extirpate or remove that vermin. (p. 305) 
The communication between the two shows that the "good men" were capable of committing extremely heinous crimes.

Another reason, due to which the Aboriginal culture came to brink is dislocation. In case of spread of outbreaks of small pox, Erdrich seems to give benefit of doubt to the whites but she is very vocal about the issue of dislocation and not honoring the treaties by the whites. The Indian was dislocated from their native lands because he was a "primitive hunter" (Maddox, 1991, p. 151) who did not "alter land to his own specifications" (Sheehan, 1969, p. 328). For the whites, agriculture was one of the criteria to determine the civilizational advances of the people. In this case the Native Americans were the "first to grow potatoes, tomatoes and many other food staples that continue to provide nourishment for people throughout the world today" (Saurman, 2012, p.2). The achievement of Native Americans goes much beyond growing crops:

The land-and water-wise people were the pioneers of what is one of the longest-running, most stable irrigation cultures in the history of the planet. (Page, 2003, p. 73)

These people according to Jake Page were not hunter gatherers:

They had made significant changes in the nature of the American landscape, clearing plots of land, diverting streams, creating irrigation channels, building huge mounds, burning large area to encourage new vegetative growth and the presence of such animals as deer. Fire was used as herding device. The Indians were, to the degree they were capable, engineer of the landscape. (Page, 2003, p. 92)

The whites needed the land, so all their "impressive cultural and agricultural advances" (Satz, 1974, p. 19) were ignored. Now because Indians were declared "Hunters and wanderers" by U.S. government who "neither dwelt nor made improvements" to land so they had "no rights" (Satz, 1974, p.19). The greed of the white man for land was insatiable. Louise Erdrich is critical of this. One of the Native character Fishtail says:

"Not until they have it all" said Fishtail. "All of our Lands, our wild rice beds, hunting ground, fishing streams, gardens. Not even when we are gone and they have the bones of our loved ones will they be pleased. I have thought about this." (p. 8o)

The reason behind this greed is that they "must have starved as ghosts" (1999,p.80).They are infinitely hungry.

Louise Erdrich is critical of government as well as of the whites. The land was taken from the Indians after they signed treaties. President Adams, in his message of 1828 , described the policy of the U.S. government towards Indians:

At the establishment of the Federal government the principle was adopted at considering them as foreign and independent powers, and also as proprietors of the lands. As independent powers, we negotiated with them by treaties; as proprietors, we purchased of them all the land we could prevail on them to sell; as brethren to the human race, rude and ignorant, we endeavored to bring them to the knowledge of the religion and letters. (qtd. In Jackson, 1889, p. 16)

In the above statement, the two words that are important are "proprietors" and "purchased." After reading this statement, one gets the impression that the land of the Natives was purchased from them and they were not forced to sell the land. Erdrich exposes such claims of the white government. The Natives in the novels are told that they "must leave the island" (p. 77). Use of word "must" makes it clear that Natives were not given a choice, they were forced to 
leave the island. The government was also involved in it. The treaties were lopsided where the treaties were framed in English, a language alien to the Ojibwe. In the novel, readers came across the Native who are learning "chimookoman's tracks" [writing system] (1999,p. 12), so that the whites cannot "cheat" them "with the treaties" (1999, p. 112). The novelist also raises the questions about the issue of the payment. The treaties are made by the white man on the island, but the payments are made at a "western post" (1999, p. 78). The novelist raises the important question about the method of payments in the novel, but the readers get the answer in the second novel of the series The Game of Silence. In the second novel, the novelist shows that Natives are betrayed by the whites and instead of paying them the money; the whites exterminated them by providing poisoned flour (Erdrich, 2005, 197). This hypocrisy of the white U.S. government was exposed by Theodore Frelinghuysen who asked if the "obligations of justice change with the color of the skins?" (Satz, 1974, p. 22).

Erdrich exposes the lies of the whites in the novel. She makes it clear that the Natives were not the hunters and gatherers as portrayed by the colonial narratives, rather they lived a settled life and practised agriculture (1999, p.56).

The whites paved the way for a great humanitarian disaster. The Natives were pushed away from their lands and no proper arrangements were made to transfer them to the designated lands. Louise Erdrich lists the hazards on the way: "Dakota war parties, hunger, the threat of the winter's dire weather" (1999, p. 79). Erdrich's claim is supported by Wilcomb E. Washburn (1965) who writes about the policy of dislocation:

To say that the movement was a success administratively, however, is only to say that the bodies were removed from the land wanted by the whites. It does not say even that the bodies had to reach the lands to which they were sent. Many Indians died enroute from cold, starvation, sickness and other causes which could have been prevented had the power been as much concerned about seeing that Indians got to the lands allotted them as they were in removing them from the lands desired by the whites. (p. 275)

The whole matter of dislocation was observed by many outsiders. One of them was Alexis de Toqueville (2013) who wrote:

The Spaniards were unable to exterminate the Indian race by those unparalleled atrocities which brand them with indelible shame, nor did they even succeed in wholly depriving it of its regions; but the Americans of the United States have accomplished this twofold purpose with singular felicity, tranquilly, legally, philanthropically, without shedding blood and without violating a single great principle of morality in the eyes of the world. It is impossible to destroy men with more respect for the laws of humanity. (p. 357)

The disastrous policy of dislocation did result in the destruction of the Natives. They had a special affiliation, association with the land. With dislocation that association was snapped. The people who survived the dangerous journeys to the designated lands were debilitated by the policy. The Natives treat land as their "mother" who is the "ultimate giver" and "nurtures" with "food crops" and "medicines." (Spruce, 2008, p. XI). With dislocation the bond between the mother and her children was broken and the people who survived developed psychological problems. The spillover effects of this dislocation are still visible among the Natives as the "Rates of suicide among Native Americans are the highest compared to the other groups and they keep increasing over the years" (Racine, Eliza, 2016). Even after dislocation, the people maintained their relations with the "mother earth" to rejuvenate themselves psychologically and physically: "Long ago it was traditional custom to return to one's birth place now and then and roll in earth there" 
(qtd. in Beck, 1980, p. 334). The same is articulated by the community leader who requested that he "shall be returned to the place" where he was born (qtd. In Nabokov, 1994, 105). All these were efforts to reunite with their lost "mother."

Thus, through her writings, Louise Erdrich tries to resuscitate the culture of her people. She brings out the follies and crimes committed by the whites to usurp the land, but her stance is not confrontational. Her stance is representative of her people who were destroyed by the policies of the white government. But did not develop an ill will. The stance of her people is articulated by Omakayas in The Game of Silence (2005):

You will not take leave of your beloved and beautiful home in bitterness or in anger. You will not take leave in hatred. You are stronger than that. When the Anishinabeg must give way to a stronger force, they do so with dignity of love (236).

Thus, the white lies inherent in colonial discourse had dubbed and dismissed Natives as savages; the narratives circulated by the colonizers gave currency and sanctity to the white perspective. However, it was later with emergence of postcolonial Aboriginal narratives that the colonial lies were exposed. The discursive practices that create convenient categories allowing dehumanization of the suppressed are laid bare as the readers realize how truth is glossed over and brutalities shamelessly wrecked in the name of civilization.

Disease, deprivation and dislocation took its toll on these innocent Natives who had trusted the White man's words. Now, words were to be counteracted with words; narratives with narratives; tales with tales; and at last, discourse with discourse.

\section{References:}

Achebe, Chinua. (1977). An Image of Africa: Racism in Conrad's Heart of Darkness. Massachusetts Review 18. Web.www.polonistyka.amu.edu.pl.

Anderson, Margaret L. \& Howard F Taylor. (2004). Sociology. Belmont: Thomson Wadsworth.

Beck, Peggy V. \& Anna L. Walters. (1980). The Sacred: Ways of Knowledge, Sources of Life. Arizona: Tsaile.

Cesaire, Aime. (2010). Discourse on Colonialism. Delhi: Aakar Books.

Coltell, Laura. (1990). Louise Erdrich and Michael Dorris. In Winged Words: American Indian Writers Speak. Lincoln: University of Nebraska Press, 40-52.

Corin, E. (1995). The Cultural Frame: Context and Meaning in the Construction of Health. In B.C. Amick, S. Levine et al Society and Health. New York: Oxford University Press.

Cushner, Nicholas P. (2008). Why Have You Come Here? The Jesuits and the First Evangelization of Native America. New York: Oxford University Press.

Erdrich, Louise. (1999). The Birchbark House. New York. Hyperion.

Erdrich, Louise. (2005). The Game of Silence. New York: Harper Collins.

Goodman, Jo \& Sophie Grig.(2007). Progress Can Kill. London: Survival International. Web. http://www.survival-International.org.

Henslin, James M. (2005). Sociology. Boston: Pearson.

Hofstede, Greert and McCrae. (2004). Personality and Culture Revisited: Linking Traits and Dimensions of Culture. Cross Cultural Research 38. 1, pp. 52-88. 
Jackson, Helen Hunt. (1889). A Century of Dishonor. Boston: Roberts Brothers.

Jaskoski, Helen. (1996). A Terrible Sickness among Them. In Helen Jaskoski (ed.) Early Native American Writing. New York: Cambridge University Press.

Kelley, Robin D.G. (2010). Introduction. In Aime Cesaire Discourse on Colonialism Trans. Joan Pinkam. Delhi: Aakar Books.

Kornblum, William. (200o). Sociology in a Changing World. Forthworth: Harcourt College Publishers.

Langton, Marcia. (1999). "Breaking Taboos" Response to Alexis Wright. Australian Humanities Review. Web. <http: www.australianhumanitiesreview.org>

Larson, Sidner. (200o). Captured in the Middle. Seattle: University of Washington Press.

Lewis, David. (1993). Still Native: The Significance of Native Americans in the History of Twentieth Century. Western Historical Quarterly, 24.2, 203-227.

Maddox, Lucy. (1991). Removals. New York: Oxford University Press.

Memmi, Albert. (1991). The Colonizer and the Colonized. Boston: Beacon Press.

Nabokov, Peter and Larry Loendorf. (1994). Every Morning of the World: Ethnographic Resources Study of the Bighorn Canyon National Recreation Area, National Park Service: National Forest Bureau of Land Management.

Page, Jake. (2003). In the Hands of Great Spirit. New York: Free Press.

Parkman, Francis. (1851). The Conspiracy of Pontiac and the Indian War after the Conquest of Canada.Web. Project Gutenberg.

Pols, Hans. (2007). Psychological Knowledge in a Colonial Context: Theories of the "Native mind" in the Former Dutch Indies. History of Psychology 10.2, 111-131. Web. http://www.apa.org.

Pratt, Mary Louise. (1991). Arts of Contact Zone. Profession, 33-40. Web. JSTOR.

Prucha, Francis Paul. (1984). The Great Father Vol 1. Lincoln: University of Nebraska Press.

Racine, Eliza. (2016). Native Americans Facing Highest Suicide Rates. Web. http://lakotalaw.org/news/201605-12/native-americans-facing-highest-suicide-rates.

Ryan, Lyndall. (1981). The Aboriginal Tasmanians. St. Lucia: University of Queensland Press.

Sanders, Andrew. (1984). The Short Oxford History of English Literature. Oxford: Clarendon Press.

Satz, Ronald A. (1974). American Indian Policy in the Jacksonian Era. Lincoln: University of Nebraska Press.

Saurman, William E. (2012). We've Done Them Wrong! Bloomington: I Universe, Inc.

Sheehan, Bernard W. (1969). Paradise and the Noble Savage in Jeffersonian Thought. The William and Mary Quarterly 26.3, 327-359.

Spruce, Duane Blue \& Tanya Thrasher. (2008). The Land has Memory. University of Carolina Press.

Stearns, Peter N. (2003). Reassuring "White Australia”: A Review of Fabrication of Aboriginal History Vol One, Van Diemen's Land. Journal of Social History 37.4, 1131-1135.

Toqueville, Aleis De.(2013). Democracy in America. Trans. Henry Reeves. Web. http://

www.gutenberg.org/files/815/815-h.htm

Vizenor, Gerald. (1984). The People Named Chippewa. Minneapolis: University of Minnesota Press.

Washburn, Wilcomb E. (1957).A Moral History Indian-White Relations: Needs and Opportunities for Study. Ethnohistory 4.1, 47-64 
.Washburn, Wilcomb E. (1965). Indian Removal Policy: Administrative, Historical and Moral Criteria for Judging Its Success or Failure. Ethnohistory 12.3, 274-278.

Washburn, Wilcomb E. (1968). Philanthropy and the American Indian: The Need for a Model. Ethnohistory 15.1, 43-56.

Whipple, H.B. (1880). Preface. In Helen Hunt Jackson A Century of Dishonor. Boston: Jackson Brothers.

Wong, Hertha D. Sweet. (2008). Introduction. In Hertha D. Sweet Wong \& Lauren Stuart Muller et al. (ed) Reckonings: Contemporary Short Fiction by Native American Women. New York: Oxford University Press.

Virender Pal Teaches English at Institute of Integrated and Honors Studies, Kurukshetra University Kurukshetra. He has done his Ph.D. on Australian Aboriginal literature. He is the author of several academic papers and has completed a UGC sponsored minor project on "Debunking Dalit Stereotypes: A Study of U.R. Ananthamurthy's Novels." His interests include Native literature and Indian literature. His ORCID ID is oooo-0003-3569-1289. 